\title{
ORGANIZATION OF THE EDUCATIONAL PROCESS OF UNIVERSITIES OF TECHNICAL SPECIALTIES IN THE COUNTRY OF TRENDS OF THE SOLUTION OF THE HUMANITARIAN-CULTURAL ENVIRONMENT AMONG STUDENT YOUTH
}

\author{
Iryna Chernikova \\ Department of Pedagogy \\ Volodymyr Dahl East Ukrainian National University, \\ 59-a Centralnyy ave., Severodonetsk, Ukraine, 93400 \\ ChernikovaID@ukr.net
}

\begin{abstract}
The connection of Ukraine with the world and European community implies a focus on the Person, his/her spiritual education, upbringing of value attitude to the social environment and him/herself, with a thorough education and deep knowledge, the ability to successfully solve his/her own life problems, readiness to take on the responsibility conditions of international relations, capability of self-development and self-improvement, responsibility for other people. This fundamental approach requires a rethinking of the process of education in universities with a technical profile of training specialists, and in general in the educational system of the state. The problem of development of the Concept of educational system of the modern higher technical educational institution for today and the necessity of finding effective ways of formation of world outlook positions and values landmarks of the student youth on the basis of spiritual, moral and cultural bases of life of the Ukrainian people, coordination of interaction of educational institutions of professional education, state institutions are considered.
\end{abstract}

Keywords: education, spiritual values, humanization, competence of specialists, competitiveness.

DOI: $10.21303 / 2504-5571.2020 .001183$

\section{Introduction}

The problem of creating an educational system of a higher technical educational institution has become urgent due to a number of contradictions:

- between the realization of the Person as the highest value on the one hand and the lack of educational institutions of Institution of Higher Education, which would offer values at the educational system level;

- between the dynamic changes in the society that transform human values and the inability to resist the negative impact of these changes in the sphere of human values;

- between declaring spiritual values and the inability of the student youth to virtually improve themselves due to their inertia;

- between the needs of greater moral obligations for the sake of the well-being of the society and the rapid nature of change in the society, etc.

One of the main indicators by which the level of development of individuals, countries, people and communities is measured is education.

The international community, represented by UNESCO through its three major programs in the field of development of education «Education for all», «Development and implementation of education policies» and «Education, training and society», and within the framework of their implementation, defines the main goals:

- elimination of illiteracy, study of general problems of development of educational systems and development of theoretical and practical approaches in their reformation and improvement, taking into account national, racial and ethnic strata of the society of the countries, participating in the organization and fundamental right of each person, irrespective of age, gender and social status;

- development of consistent practical and theoretical policies of the member countries of the organization - to create appropriate current education systems and support them at the state level;

- to integrate methods and practice of interaction of education and training with the processes, taking place in the society of the participating countries: education and politics; education 
and economy; education and problems of social adaptation; education and sphere of professional work; education and culture; education, science and technology; education and humanization of society; education and communication; education, human health and sports.

The conceptual foundations of the educational system in institutions of higher education of the technical direction can be traced in the writings of domestic scientists: education of a personality from the standpoint of psychology [1]; paradigmatic principles of education, ie the principle of development of a person, individual, personality, citizen as the goal of the educational process [2], as well as the correspondence of the ways of development of education, its tendencies and perspectives to the general directions of social development of the society [3]; theory and methodology of education of the student youth [4]; peculiarities of educational work in universities with technical specialties [5], teaching and upbringing in higher education [6]; educational systems of ZVO and education of student's personality, spiritual culture of students [7] and others.

The concept of educational system of higher education institutions of technical direction is formed by interdependent components. A component is an integral part, an element of something. The structure of the basic component is: personality consciousness, emotional and emotional sphere, skills, behaviors. The concept defines the fundamental principles of the educational system, its main goals, forms and methods.

Feelings reflect persistent emotional experiences of a person arising in the course of his/her relations with the outside world. Feelings are formed and produced during the development and upbringing of a person, evoke positive or negative emotions (joy, love, pride, anger, sadness, shame, etc.). Feelings, unlike affect and emotion, are over situational.

Instinctively similar components of skills that are fully automated and implemented at the level of their unconscious control reflect skills. If you understand the part of an activity that has a conscious purpose, then a skill can also be called an automated purposeful action. Skills - the result of knowledge, obtained as a result of generalized historical experience, the result of mastering of reality and its comprehensive knowledge by a personality [8].

Human behavior, as a special form, manifested in the tendency to repeatedly perform the same actions in similar, ie identical situations, is nothing more than a habit. When a person performs certain actions constantly, then he/she subconsciously has a desire or need to do them constantly and again automatically - this is a habit. In other words, a habit is a special form of human behavior, which is manifested in the tendency to do certain actions that are entrenched as a result of their repetition.

Education of a competitive specialist is a competent approach in the process of high education, which involves acquistion of knowledge skills through purposeful actions, the essence of which is that students work on acquiring and expanding independent experience to solve real-world problems[9], learn and develop their skills of adapting in different situations and find the best solutions. The most important competencies (in our opinion) are: social competence, personal competences, communicative competences (teamwork, leadership, ethical obligations, language, working in an international context, ability to cooperate and find targeted solutions), creative competencies, the development of which contributes to the formation of a professional as a person.

Aim of research. To develop a methodology that promotes education to fulfill an extremely important task - to educate not just an educated person with a broad outlook, but a person who is a comprehensively developed, holistic, thoughtful, active, creative, socially responsible, humanitarian «Culture Man», oriented in life not only according to human values, but also according to the human values of a competitive specialist.

\section{Materials and Methods}

The concept of the educational system of universities with training of specialists in the technical field also has certain elements, namely:

1) general provisions (purpose; methodical basis: basic provisions of the theory of pedagogy and fundamental knowledge of professional disciplines; approaches to the process of learning and its conception, application and its limits; specifics of subjects of the educational process; conditions 
of development of the educational system and its effective functioning; assignment of the concept of education; possibilities of realization of the educational concept, etc.

2) universal properties, the relation of objective reality to the content of the pedagogical process (forms, methods, means of education), theoretical and methodological foundations of this process, its semantic core, the semantic filling of educational conceptual truth and its substantiation with sufficient evidence.

The concept of «competition» comes from the Latin «concurrentia» which means «collision», «competition». The training of qualified specialists, which fully meets the modern world and national requirements of the development of economy and science, is a priority task on the way to creating a competitive high-tech country. One of the characteristic reasons for the occurrence of youth unemployment in Ukraine is, first of all, the inconsistency of the training structure with the requirements of the economy and the low level of competitiveness of graduates of educational institutions. In addition, the imperfection of the education system and the lack of coordinated links between educational institutions, the state and economic entities aggravate the problem of providing training for competitive professionals. Under these conditions, the question of the need to develop mechanisms for reforming the education system and to bring the results of training in line with current requirements becomes urgent. The prerequisite of this process should be a comprehensive assessment of the quality of training of modern specialists to the requirements of employers, which will provide objective information on the problematic and critical issues in the competence of the young workforce and make the proposed measures to reform the training process more substantive.

In these circumstances, the question of the need to develop the educational process in accordance with the current requirements of economic entities becomes urgent. Therefore, an integrated component of this process should be a comprehensive assessment of the quality of training of professionals, issued by employers' requirements, which will provide objective information on the problematic and most critical issues of the quality of training of young professionals and make the proposed measures for reforming the educational process more expedient.

Many scholars and education professionals see the problem of improving the quality of university youth education as central to reforming the industry as a whole. The main thing today is the awareness and understanding of what competitiveness is and how it can be enhanced. The quality of education is such a dynamic and complex nature of education, the aggregate properties of which are capable of satisfying employers, their ever-growing demands and needs, the structural components of which are: satisfaction of the subjects of both education and economic entities with the results of the educational process; quality of educational programs; high level of qualification of scientific and pedagogical staff; the ability of the university to innovate; staffing of laboratories with a modern technical equipment, approval of public administration. Qualitative education is not only a productive professional knowledge, but also the development of a humanitarian and cultural personality - «People of Culture» $[10]$.

Not only the unity of the ideas of humanitarian and highly professional education should be placed in the quality of education, but also to see the end result of the process of competitiveness in the labor market we aspire to. Modern universities with a technical education profile are not just designed to give the young generation the amount of knowledge, abilities and skills, but must make the student youth competent and able to independently acquire and apply knowledge in different life situations, ready to take responsibility, be active in public life, understand the society and respect the history and culture of the people, and most importantly be competitive professionals in the labor market.

The correlation between the level of professional training and personal and humanitarian qualities of a teacher, working at the university, is quite ambiguous and complicated. Educating a competitive specialist requires a teacher to improve methodical manuals for conducting practical and seminars in the educational process, the ability to solve and coordinate issues with employers in the preparation of comprehensive training programs. Therefore, reconciling these problems gives rise to many conflicting and mutually exclusive approaches, ideas and positions.

The educational system creates a set of educational goals; people who implement them in the process of purposeful activity; relations that arise between its participants; development of 
environment and management activities to ensure the vitality of this system, which creates a qualitatively new environment for the development and formation of a personality.

Creating an educational system is not an end in itself. It is created and improved for the purpose of personal development of a person and depends mainly on the joint efforts of teachers, students and society.

The involvement of the Ukrainian nation in the modern European community depends on the formation of the Ukrainian democratic identity, the development of the spiritual heritage of Ukraine. Knowledge of one's own culture, history, values and traditions is an integral feature of the humanitarian development of a society. Ukraine's accession to the community of states is associated with increasing the role of culture in the Ukrainian society, the representation of knowledge as the main correlates of ideological value transformations.

At the heart of the problems of the economic functioning of the society is a component of values. Market relations, a democratic system that replaced the administrative system at the end of the twentieth century, were unable to absorb the Ukrainian society due to the deformation of the outlook, which required changes to adapt to the new conditions of creation of a sovereign state. At this stage, there is a decrease in budget funding for culture. Saving the state in the humanitarian sphere for a long time did not contribute to solving the economic development of the country.

In order to overcome the negative factors, the Ukrainian state must develop means of support, above all, for the development of segments of the population, namely: to create the conditions for the disclosure and realization of the creative, intellectual and moral abilities of an individual, the «Person of Culture». Attention to issues of the national culture is of particular importance in the context of the globalization integration processes, in which Ukraine seeks to participate. In order not to dissolve in the modern geopolitical space, our state needs to create a model of development of the society in the national space, which must be based on such components as intelligence (information potential of knowledge of a specific person, obtained as a result of functioning of consciousness, thinking and human mind), humanitarian culture (the set of material and spiritual values, created by mankind throughout its history; a historically acquired set of rules within the society for its preservation and harmonization), innovative activities (commercialization of research and development and release of the market of competitive goods and services). These components are the main resource of the state for solving the internal differences of the social development in Ukraine, and therefore for the economic recovery and the formation of social and public relations. This, in turn, requires a significant expansion of the process of humanitarian and cultural education of te student youth in universities with a technical training profile.

Most scholars of the international community believe that in the 21st century, the humanitarian component of education will be the main (desire) development of education in universities with the technical direction of specialist training. The main objective of the approach in the educational process is to prepare a highly professional specialist as a humanitarian cultural person [11] who knows the traditions and history of his/her people; can realize their creative abilities; knows how to work in a team. According to scientists, a modern bachelor, master, in addition to professional knowledge and skills, should be a carrier of the high general culture, which is formed by humanities, social sciences. The humanitarian knowledge helps the professional to become a professional creator, not just a performer. Therefore, one of the significant and urgent problems of higher technical education today is: simultaneously with highly professional special professional training, to provide students with humanitarian training, at the same time to carry out the humanization of higher education. The humanity disciplines at technical universities are generally quite tense.

From the outside, the development of technology seems to be a progressive phenomenon, but the scientific and technological progress violates the harmony between material and spiritual forces. This leads inexorably to the imbalance between culture and civilization.

At the present stage, scientific and technological progress is ahead of the social and cultural development of the society. The advance development of technology leads to the technological engineering of the society, technology holds a dominant position over the human community, dictates its will and laws. 
Therefore, it is necessary to find out the role and circumstances of humanitarian training in universities with technical specialties.

The task of the article to determine the role and features of humanitarian training of future specialists in the universities of technical specialties on the basis of scientific and pedagogical sources, to identify the problems of humanitarian training and to identify ways to solve them. In today's Ukrainian higher technical school it is necessary to state the sad fact that the attitude to the humanitarian training of students now in both of Institution of Higher Education and the Ministry of Education and Science is rather specific and not always positive. There are two reasons for this:

- firstly, the old, unguided, educational management practices are inefficient, cumbersome, and with a low-initiative attitude to innovation;

- secondly, the negative reaction of some teachers of higher technical institutions to the special situation of the humanities.

\section{Result}

The humanities in the XXI century show such a tendency and peculiarity in the humanities education as interdisciplinarity (especially in the examples of foreign higher education institutions).

First, this tendency is manifested: in the close correlation of the humanities with the professional training of specialists of a technical profile on the basis of combining specially selected «blocks» in the fields of philosophy, ethics, aesthetics, psychology and pedagogy with the formation of «sense of confidence in yourself and others". The thus formed interdisciplinary complex should become the basis of humanitarian knowledge, since it combines a significant theoretical layer with subsequent professional implementation.

Secondly, the interdisciplinary approach reflects the tendency to create a «block» of humanities and natural sciences. In the USA, Canada, for example, the following integrated courses have been introduced into the educational process: Technology in Literature, Technology and Social Values, and the Social Impact of Social Progress.

Researchers identify pedagogical, generally didactic and psychological conditions that contribute to the formation of scientific concepts of an interdisciplinary model of learning:

- semester study of the agreed individual disciplines, when each of them is based on the previous conceptual base and prepares students for mastering the concepts of the next discipline;

- the need to ensure continuity in the development of concepts (ideas); concepts that are common to a range of disciplines must be progressively evolved from discipline to discipline, filled with a new content, enriched with new connections;

- unity in the interpretation of general scientific forms of thinking, which show the relation of humanities and professional disciplines in their contradictions and development;

- elimination of duplication of the same concepts in the study of different disciplines;

- implementing a unified approach to discovering the same areas of access to concepts.

The principle of interdisciplinary integration should be the main mechanism for optimizing the structure of the knowledge model in the discipline system. The digital generation [12], as a new historical phase in the development of civilization, in which the main results of production are information technologies and information knowledge, is characterized by an increase in their role in the society. Informatization of education has made real the application of various technologies and models of integrated learning, such as:

- a transdisciplinary model of training, which involves the integration of disciplines into a single training course, the integration of standards and requirements of customers;

- an interdisciplinary (problematic) model of learning that involves learning in the process of working on a project; model of practical orientation of training on the performed functions, branches of technology, workplace, spheres of the professional activity.

The process of modernization and optimization of the educational system of higher technical education poses fundamentally new requirements, which are first and foremost aimed at fulfilling new tasks and in humanitarian training as well, among them the adaptation of a young person to rapid changes in the society. 
Ways and directions of optimization of innovative technologies of educational process in modern conditions are directed at preparing a highly competent and highly professional specialist, competitive in modern conditions - globalization and European integration, based on the following components:

1) reliability and stability of knowledge (fundamental);

2) competence and high education qualification (professionalism);

3) actual and practical education (heuristic knowledge);

4) corporate education (competence); ization);

5) social education (characterized by realization and ability to unite the society - social-

6) humanitarian and cultural education (preparedness of a specialist as a highly professional humanitarian and cultural person).

Innovative technologies of the educational process in the XXI century are addressed to the person-person relations, enriched with the synthesis of knowledge, which includes education, science, culture, knowledge, education, intelligence. It should be a synthesis of humanitarian, economic, technical, legal knowledge. That is, education of the XXI century must form a systematic thinking, based on a competency-based approach.

Components of the educational system:

- teachers' activity;

- management activities, aimed at creating conditions for the decision of the educational process;

- educational means (content, forms and methods of the educational work).

The regularity of the educational system is the connection between its components, they are the essential connections, on which the optimality in the educational processes depends.

The factor that has a significant influence on the management of the process of social development of the student's personality is the environment.

The functioning of the educational system involves the interaction of its elements on the basis of the implementation of internal and external relations, which allows to achieve certain results in educational activities.

Educational systems are relatively independent and holistic, which directly generate the development of a young person.

The essence and purpose of qualitative updating of higher education in the XXI century is to prepare a specialist, capable of mastering any specialty.

In order to prevent technocratic thinking while using the potential of fundamental disciplines, it is necessary to instill knowledge in the disciplines of the humanities for the complex solution of professional problems and the formation of one's personality, which creates only benefits for humanity. This is possible only on the basis of interdisciplinary integration, a new didactic concept of a holistic institution of higher education. The process of humanitarian preparation at a technical university needs change and reform. However, the traditional practice of technical higher education does not provide the necessary unity between the humanities and vocational training of students, so changes need to be made, both at the national level and at the level of technical higher education institutions. The comprehensive study of the problem of integration in the humanities education has confirmed its importance and positive impact on the educational process, so it should continue to be investigated.

\section{Conclusions}

In order to successfully resolve the issues of the learning process in higher education, it is necessary to create the conditions for the formation of a professional and humanitarian competent personality - «Culture Person», capable of self-determination and professional creativity. To solve this type of activity in higher education institutions of the technical direction, it is necessary to provide the purposeful and systematic work, focused both on creating favorable conditions for spiritual, intellectual and physical development, as well as on the formation of socially significant qualities, attitudes and value orientations of a person, who will promote creative self-realization 
of the personality of the future competitive specialist. Therefore, it is especially important to analyze the processes of conscious development of an individual and, above all, the formation of his/ her moral and aesthetic ideal, as purposeful attitudes, which should ensure the convergence of an individual to his/her perfection, realization of life self-determination and search for methods of self-realization.

\section{References}

[1] Bekh, I. D. (2015). Osobystist u konteksti oriientyriv rozvyvalnoho vykhovannia. Innovatyka u vykhovanni, 1, 9-13.

[2] Fokin, Iu. G. (2002). Prepodavanie i vospitanie v vysshei shkole. Metodologiia, tseli i soderzhanie, tvorchestvo. Moscow: Akademiia, 224.

[3] Andrushchenko, V. P. (2005). Orhanizovane suspilstvo. Problema orhanizatsii ta suspilnoi samoorhanizatsii v period radykalnykh transformatsii v Ukraini na rubezhi stolit: dosvid sotsialno-filosofskoho analizu. Kyiv: TOV «Atlant YuEmSi», 502.

[4] Antonenko, T. L. (2009). Cinnosti i smysly iak komponenta kompetentnosti. Informaciyni tehnologii i zasoby navchannia, 6 (14). Available at: https://journal.iitta.gov.ua/index.php/itlt/article/view/217/203

[5] Luchaninova, O. P. (2016). The concept of the pedagogical system of the higher technical educational establishment: essential characteristics of its components. ScienceRise, 3 (5 (20)), 63-68. doi: http://doi.org/10.15587/2313-8416.2016.64818

[6] Savosh, H. P. (2014). Vykhovannia yak sotsializatsiina skladova vyshchoi osvity Ukrainy v protsesi intehratsii do yevropeiskoho prostoru. Vyshcha osvita Ukrainy u konteksti intehratsii do yevropeiskoho osvitnoho prostoru. Kyiv: Mizhnarodna ekspertna ahentsiia, «Konsaltynh i Treninh» ta Skhidno-Yevropeiskyi instytut psykholohii, 43-49.

[7] Shevchenko, H. P. (2016). Kultura i mystetstvo v idealotvorenni osobystosti. Dukhovnist osobystosti: metodolohiia, teoriia i praktyka. Zbirnyk naukovykh prats SNU im. V. Dalia, 6 (76), 294-305.

[8] Aver'yanova, N. O. (2007). Natsionalne vykhovannia v konteksti hlobalizatsii. Visnyk KNU im. T.Shevchenka. Seriia: Ukrainoznavstvo, 11, 53-56.

[9] Sokolov, V., Krol, O., Stepanova, O. (2019). Nonlinear simulation of electrohydraulic drive for technological equipment. Journal of Physics: Conference Series, 1278, 012003. doi: http://doi.org/10.1088/1742-6596/1278/1/012003

[10] Zelenov, E. A. (2016). Spiritual Foundations of Planetary Students Education. Dukhovnist osobystosti: metodolohiia, teoriia, praktyka, 3 (72), 346-352.

[11] Shevchenko, H. P. (2015). Vykhovannia - protses liudynotvorchosti, kulturotvorchosti, dukhotvorchosti. Dukhovnist osobystosti: metodolohiia, teoriia i praktyka, 3 (66), 288-299.

[12] Zelenov, E. A. (2018). Tsyfrove pokolinnia: ryzyky, perevahy, zasoby vzaiemodii. Dukhovnist osobystosti: metodolohiia, teoriia i praktyka, 5 (86), 46-57. 